\title{
A single nucleotide polymorphism in the UMOD promoter is associated with end stage renal disease
}

\author{
Tingyu Chen', Qianliao Wang ${ }^{1}$, Guisen $\mathrm{Li}^{1,2^{*}}$ and Li Wang ${ }^{1,2}$
}

\begin{abstract}
Background: Several genome-wide association studies revealed that several variants of UMOD gene were related to the estimated glomerular filtration rate (eGFR), CKD or hypertension. In this study, we investigated the association between a common variant rs13333226 in the promoter region of UMOD gene and end stage renal disease (ESRD).

Methods: Variant rs13333226 of UMOD gene was genotyped by using the ABI Real time TaqMan allelic discrimination assay in a case-control study including 638 unrelated patients with ESRD and 366 controls.

Results: The frequency of UMOD SNP rs 13333226 GG/GA genotype was significantly higher (36.83\% vs. 20.22\%, $P=4$. $\left.02 \times 10^{-8}\right)$ and the frequency of $G$ allele was much higher $\left(19.04 \%\right.$ vs. $\left.11.20 \%, P=4.00 \times 10^{-6}\right)$ in the patients with ESRD than in the controls. The $\mathrm{G}$ allele was associated with an increased risk of ESRD (odds ratio 2.30, 95\% confidence interval $1.70-3.11, P=6.10 \times 10^{-8}$ ). And $\mathrm{G}$ allele (odds ratio $2.33,95 \%$ confidence interval $1.32-4.13, P=3.65 \times 10^{-3}$ ) was associated independently with ESRD.
\end{abstract}

Conclusions: A common variation rs13333226 in the promoter region of UMOD gene was independently associated with ESRD in Han Chinese.

Keywords: End stage renal disease, Single-nucleotide polymorphism, UMOD

\section{Background}

End stage renal disease (ESRD), was one of the most serious principal challenges and resulted in a serious public health and financial burden worldwide. In addition, ESRD caused high morbidity and was an independent risk factor for cardiovascular disease or overall mortality in patients with chronic kidney disease (CKD) $[1,2]$. It affected over $0.03 \%$ of the Chinese adult population [3].

Multiple factors were involved in the progression of kidney diseases into ESRD, and the development of ESRD was the result of interaction between genes and environment [4-7]. Familial clustering phenomenon was common in patients with ESRD $[4,5,7,8]$. A recent study reported that a CKD patients, who had a first-

\footnotetext{
* Correspondence: guisenli@163.com

${ }^{1}$ Renal Division and Institute of Nephrology, Sichuan Provincial People's Hospital, No. 32, West 2nd Duan, 1st Circle Rd., Qingyang District, Chengdu, Sichuan 610072, People's Republic of China

${ }^{2}$ School of Medicine, University of Electronic Science and Technology of China, No. 32, West 2nd Duan, 1st Circle Rd., Qingyang District, Chengdu, Sichuan 610072, People's Republic of China
}

degree relative with ESRD, significantly increased the relative risk of developing ESRD [8]. Polymorphisms of many genes were reported to be associated with ESRD, such as ACE, APOL1, and MUC1 [7].

Recently, several genome-wide association studies (GWAS) showed that lots of genetic risk loci (such as: rs12917707, rs4293393, and rs6497476) were associated with estimated glomerular filtration rate (eGFR), CKD or hypertension [9-13]. Most studies consistently showed that the common variant rs12917707 of the UMOD gene have been strongly associated with eGFR, prevalent and incident CKD and ESRD in general population cohorts $[9,11,14]$. The relationship between $\mathrm{T}$ allele of rs12917707 and lower risk of CKD and ESRD was confirmed in other two case-control studies $[15,16]$. These results suggested that the variants of UMOD gene contributed to the genetic susceptibility to ESRD. But a study recently reported that the association between rs12917707 and GFR was not observed in Italian diabetic patients [17]. And the minor allele frequency of 
rs12917707 (T allele) was only 1\% in Han Chinese (http:// hapmap.ncbi.nlm.nih.gov/index.html.en). Another single nucleotide polymorphism (SNP) in the promoter region of UMOD gene, rs13333226, was reported to be associated with hypertension, and serum uric level $[18,19]$. The G allele carriers had higher diastolic blood pressure and higher plasma uric acid compared with A/A homozygotes $[18,19]$. In this study, we explored the association between rs13333226 and the susceptibility to ESRD.

\section{Methods}

\section{Patients and clinical data}

Total 638 unrelated Han Chinese patients with ESRD were recruited from southwest of China. The diagnostic criteria of ESRD were eGFR less than 15 or have received dialysis (hemodialysis or peritoneal dialysis). The patient who had acute kidney injury was excluded. The average age of their onset of ESRD (CKD 5 or 5D) was $54.1 \pm 16.0$ years old (from 14 to 87 years old). The primary causes of ESRD included chronic glomerulonephritis (CGN), diabetic kidney disease (DKD), hypertensive nephropathy (HTN), as well as other causes. Three hundred and sixty-six healthy individuals served as controls. All the controls didn't have hypertension, diabetes, as well as acute or chronic kidney diseases. The average age of the controls was $52.9 \pm 13.3$ years-old (from 18 to 87 years old). The protocol was approved by the Ethics Review Committee of Sichuan Provincial People's Hospital. Informed consent was signed by all subjects.

\section{DNA extraction and genotyping}

DNA was extracted from peripheral blood collected from patients with ESRD and healthy controls by using 'salting-out' method. The genotyping was conducted by real-time PCR. The primers and probe were obtained from Applied Biosystems (ABI, Foster city, CA). Genotyping of the rs13333226 SNP in the UMOD gene was performed using an ABI 7900 Real-time System (ABI, Foster city, CA). Assays were run at a final volume of $25 \mu \mathrm{l}$ consisting of $12.5 \mu \mathrm{l}$ of $\mathrm{TaqMan}^{\circ}{ }^{\circ}$ Gene Expression Master mix (ABI, Foster city, CA), $7.5 \mu \mathrm{l}$ of primers (400 $\mathrm{nM}$ both forward and reverse) and probe (200 nM) (final concentration), $5 \mu \mathrm{l}$ of input target DNA. Genotype clustering and calling were performed using SDS 2.3 Software (ABI, Foster city, CA).

\section{Statistical analyses}

Deviation from Hardy-Weinberg equilibrium was tested in healthy controls. Comparison of genotype and allele frequency between patient group and control group was done by $X^{2}$ test. Genotype-phenotype associations were tested under dominant as well as recessive genetic model. The effect of genotype on ESRD was also investigated with logistic regression analysis. Statistical analyses were performed using SPSS 17.0 software package (SPSS Inc., Chicago, IL). Statistical power was calculated by a software "PS: Power and Sample Size Calculation" [20]. The SNP data of UMOD gene derived from $1000 \mathrm{Ge}-$ nomes project (GRCh38) CHB (Chinese Han Beijing) + CHS (Chinese Han South) were used to perform pairwise linkage disequilibrium analysis between rs13333226 and the previous GWAS hit rs12917707, rs4293393, as well as rs6497476 by Haploview software [21].

\section{Results}

The percentage of male in the cases was much higher than in the controls $\left(55.8 \%\right.$ vs. $\left.33.9 \%, P=2.20 \times 10^{-11}\right)$. The demographic and clinical data were listed in Table 1. There was no deviation from Hardy-Weinberg equilibrium in controls $(P=0.073)$. The coefficient $\left(\mathrm{r}^{2}\right)$ for pairwise linkage disequilibrium (LD) between rs13333226 and rs12917707, rs4293393, as well as rs6497476 were $0.099,1,0.883$, respectively.

Compared to the healthy controls, the frequency of UMOD SNP rs13333226 GG/GA genotype was significantly higher $\left(36.83 \%\right.$ vs. $\left.20.22 \%, P=4.02 \times 10^{-8}\right)$ and the frequency of $\mathrm{G}$ allele was much higher in the patients with $\operatorname{ESRD}\left(19.04 \%\right.$ vs. $\left.11.20 \%, P=4.00 \times 10^{-6}\right)$. The frequencies of GG/GA genotype and $G$ allele were also much higher in ESRD patients with diabetes mellitus, without diabetes mellitus, or with hypertension (Table 2). For male individuals, the frequency of GG/GA genotype was much higher in patients than in controls $(35.4 \%$ vs. $21.8 \%$, $P=5.10 \times 10^{-3}$ ), and for female individuals, the difference was significant $\left(38.4 \%\right.$ vs. $\left.19.7 \%, P=2.00 \times 10^{-6}\right)$.

The $G$ allele was associated with higher risk of ESRD in dominant model [odds ratio $(\mathrm{OR})=2.30,95 \%$ confidence interval $\left.(\mathrm{CI}): 1.70-3.11, P=6.10 \times 10^{-8}\right]$ with a statistical power of 1.00 , in an additive model $(\mathrm{OR}=1.96,95 \% \mathrm{CI}$ : $\left.1.48-2.60, P=2.00 \times 10^{-6}\right)$, but not in recessive model (OR $=0.57,95 \%$ CI: $0.21-1.53, P=0.26)$. The G allele was significantly associated with ESRD in dominant model in the subgroup of patients without diabetes mellitus $(N=538$, OR $=2.21,95 \%$ CI: $1.62-3.01, P=$

Table 1 Demographic and clinical characteristics of the participants

\begin{tabular}{llll}
\hline & $\begin{array}{l}\text { Cases } \\
(n=638)\end{array}$ & $\begin{array}{l}\text { Controls } \\
(n=366)\end{array}$ & $P$ values \\
\hline Male, $n(\%)$ & $356(55.8 \%)$ & $124(33.9 \%)$ & $2.20 \times 10^{-11}$ \\
Age $(y)$ & $54.1 \pm 16.0$ & $52.9 \pm 13.3$ & 0.13 \\
Primary causes of ESRD & & & \\
Chronic glomerulonephritis & $250(39.2 \%)$ & - & - \\
Diabetic kidney disease & $100(15.7 \%)$ & - & - \\
Hypertensive nephropathy & $87(13.6 \%)$ & - & - \\
Other causes & $95(14.9 \%)$ & - & - \\
Unknown & $106(16.6 \%)$ & - \\
\hline
\end{tabular}


Table 2 The frequencies of genotypes and alleles of rs1333326 in cases and controls groups

\begin{tabular}{|c|c|c|c|c|c|}
\hline & \multicolumn{3}{|c|}{ Genotype frequency } & \multicolumn{2}{|c|}{ Allelic frequency } \\
\hline & GG & $A G$ & AA & G & A \\
\hline Control & 8 & 66 & 292 & 82 & 650 \\
\hline \multirow[t]{2}{*}{ All cases } & 8 & 227 & 403 & 243 & 1033 \\
\hline & \multicolumn{3}{|c|}{$X^{2}=35.08, P=2.41 \times 10^{-8}$} & \multicolumn{2}{|c|}{$X^{2}=21.09, P=4.00 \times 10^{-6}$} \\
\hline \multirow[t]{2}{*}{ Cases with $\mathrm{DM}^{\mathrm{a}}$} & 2 & 40 & 58 & 44 & 156 \\
\hline & \multicolumn{3}{|c|}{$X^{2}=19.79, P=5.00 \times 10^{-5}$} & \multicolumn{2}{|c|}{$X^{2}=15.67, P=7.60 \times 10^{-5}$} \\
\hline \multirow[t]{2}{*}{ Cases without DM ${ }^{a}$} & 6 & 187 & 345 & 199 & 877 \\
\hline & \multicolumn{3}{|c|}{$X^{2}=30.96, P=1.89 \times 10^{-7}$} & \multicolumn{2}{|c|}{$X^{2}=17.65, P=2.70 \times 10^{-5}$} \\
\hline \multirow[t]{2}{*}{ Cases with hypertension ${ }^{a}$} & 7 & 202 & 360 & 216 & 922 \\
\hline & \multicolumn{3}{|c|}{$X^{2}=33.69, P=4.84 \times 10^{-8}$} & \multicolumn{2}{|c|}{$X^{2}=20.12, P=7.00 \times 10^{-6}$} \\
\hline
\end{tabular}

${ }^{\mathrm{a}}$ Compared to controls

$\left.5.55 \times 10^{-7}\right)$, with diabetes mellitus $(N=100$, OR $=2.86$, 95\% CI: $\left.1.78-4.58, \quad P=1.30 \times 10^{-5}\right)$, as well as with hypertension $(N=569, \mathrm{OR}=2.29,95 \% \mathrm{CI}: 1.69-3.11$, $\left.P=1.19 \times 10^{-7}\right)$.

The effect of genotype on ESRD was also investigated by a multivariable logistic regression analysis including age of initial ESRD, sex, hypertension and diabetic mellitus. The result showed that male $(\mathrm{OR}=2.05,95 \% \mathrm{CI}$ : 1.19-3.51, $P=9.31 \times 10^{-3}$ ) and $\mathrm{G}$ allele at rs13333226 $\left(\mathrm{OR}=2.33\right.$, 95\% CI: $\left.1.32-4.13, P=3.65 \times 10^{-3}\right)$ was independently associated with the susceptibility to ESRD.

\section{Discussion}

UMOD gene encodes Tamm-Horsfall protein, also known as uromodulin, which is a glycoprotein exclusively synthesized by the thick ascending limb (TAL) and early distal convoluted tubule in the kidney [22]. Lots of studies revealed that the variants of UMOD were associated with different risk of CKD, cardiovascular disease, hypertension, and hyperuricemia, T allele of rs12917707 was associated with lower risk of CKD and ESRD [9, 10, 18, $19,23,24]$. But the relationship between variants of UMOD and risk of kidney disease was complicated, the several rare mutation in UMOD gene has been described as a cause of uromodulin-associated kidney disease, an autosomal dominant disease $[25,26]$. Prudente et al. recently demonstrated that the previously reported strong association between rs12917707 and GFR in diabetic patients from Sweden was not observed in Italian diabetic patients [17]. It suggested that there was a heterogeneous effect across the two different samples [17]. In this study, we investigated the association between a promoter SNP rs13333226 of UMOD and susceptibility to ESRD.

Our results indicated that the frequency of rs13333226 GG/GA genotype and $G$ allele was significantly higher in the patients with ESRD, compared to healthy controls. The $\mathrm{G}$ allele was associated with higher risk of ESRD in dominant model. G allele and male was associated independently with the susceptibility to ESRD by multivariate logistic analysis. This relationship still existed after adjusted by sex, age, as well as presence or absence of diabetes mellitus and hypertension. Our results demonstrated that rs13333226 didn't correlate tightly with rs12917707 in Chinese Han population. It suggested that the effect of rs13333226 on CKD or ESRD was different from rs12917707. A previous case-control association study showed that $\mathrm{G}$ allele of rs13333226 was independently associated with a decreased risk of nephropathy, and the $G$ allele was also associated with a higher eGFR and lower systolic blood pressure in the study cohort [27]. However, two other studies have shown that G allele carriers have higher diastolic blood pressure and higher plasma uric acid compared with A/A homozygotes [18, 19].

The $\mathrm{G}$ allele at rs13333226 and C allele at rs6497476 were demonstrated to increase transcriptional activity in HEK-293 cells and mlMCD3 cells by luciferase reporter assay [19]. The rs13333226 G allele carriers have higher plasma uric acid than A/A homozygotes [19]. Higher serum uric acid was reported to associate significantly with increased risk for kidney functional impairment and SUA $\geq 6.0 \mathrm{mg} / \mathrm{dL}$ was a significant risk factor for rapid decline in eGFR [28]. In a prospective children and adolescents cohort study, those with higher uric acid levels $(\geq 5.5 \mathrm{mg} / \mathrm{dL})$ had shorter times to renal outcomes by a multivariable parametric time-to-event analysis [29]. Trudu et al. reported that two UMOD risk variants ( $G$ allele of rs12917707 and $T$ allele of rs4293393) increased UMOD expression which led to salt-sensitive hypertension and to the presence of age-dependent renal lesions in transgenic mice [24]. High expression of uromodulin could activate the renal sodium cotransporter NKCC2 which induced hypertension in UMOD transgenic mouse model [24]. UMOD has also proved to regulate the renal outer medullary potassium channel, thus 
increasing salt reabsorption along the TAL [30]. It could be speculated that the $\mathrm{G}$ allele at rs13333226 could increase carriers' risk of ESRD by enhancing UMOD gene expression, increasing TAL salt reabsorption and serum uric acid levels, as well as increasing risk of hypertension. We haven't detected serum sodium or uric acid levels in these patients, because the two parameters were influenced by many factors in patients with hemodialysis.

Although there was an independent association between G allele at rs13333226 and ESRD, we still need direct functional evidence to illustrate that whether the G allele at rs13333226 was a causal variant. And a prospective cohort study with large sample size would provide more solid evidence.

\section{Conclusions}

In summary, our data indicates that common genetic variation rs13333226 in the promoter region of UMOD gene was independently associated with ESRD in Han Chinese.

\section{Abbreviations}

CKD: Chronic kidney disease; eGFR: Estimated glomerular filtration rate; ESRD: End stage renal disease; SNP: Single nucleotide polymorphism; UMOD: Uromodulin

\section{Acknowledgments}

The authors wish to thank all the patients and control individuals for their participation and cooperation with this study.

\section{Funding}

This study was supported in part by National Basic Research Program of China 973 No. 2012 CB517600 (No. 2012CB517604, to G.L.), National Natural Science Foundation of China (81170666, to G.L.) and Youth Science and Technology Creative Research Groups of Sichuan Province (2015TD0013, to G.L.)

\section{Availability of data and materials}

The authors declare that the data supporting the findings of this study are available within the article.

\section{Authors' contributions}

Conceived and designed the work: GL, TC and WL. Collection of the clinical data: TC, QW and GL. Performed the experiments: TC and QW. Analyzed the data: TC and GL. Wrote the paper: TC and GL. All authors read and approved the final manuscript.

\section{Competing interests}

The authors declare that they have no competing interests.

\section{Consent for publication}

Not relevan

\section{Ethics approval and consent to participate}

This study was approved by the Ethics Review Committee of Sichuan Provincial People's Hospital. Written informed consent for analyses was obtained from all participants.

Received: 10 November 2015 Accepted: 2 December 2016 Published online: 09 December 2016

\section{References}

1. Weiner DE, Tighiouart H, Amin MG, Stark PC, MacLeod B, Griffith JL, Salem DN, Levey AS, Sarnak MJ. Chronic kidney disease as a risk factor for cardiovascular disease and all-cause mortality: a pooled analysis of community-based studies. J Am Soc Nephrol. 2004;15(5):1307-15.
2. Sarnak MJ, Levey AS, Schoolwerth AC, Coresh J, Culleton B, Hamm LL, McCullough PA, Kasiske BL, Kelepouris E, Klag MJ, et al. Kidney disease as a risk factor for development of cardiovascular disease: a statement from the American Heart Association Councils on Kidney in Cardiovascular Disease High Blood Pressure Research, Clinical Cardiology, and Epidemiology and Prevention. Hypertension. 2003;42(5):1050-65.

3. Zhang L, Wang F, Wang L, Wang W, Liu B, Liu J, Chen M, He Q, Liao Y, Yu X et al. Prevalence of chronic kidney disease in China: a cross-sectional survey. Lancet. 2012;379(9818):815-22.

4. Spray BJ, Atassi NG, Tuttle AB, Freedman BI. Familial risk, age at onset, and cause of end-stage renal disease in white Americans. J Am Soc Nephrol. 1995;5(10):1806-10.

5. Akrawi DS, Li X, Sundquist J, Sundquist K, Zoller B. Familial risks of kidney failure in Sweden: a nationwide family study. PLoS One. 2014;9(11):e113353.

6. Satko SG, Freedman BI, Moossavi S. Genetic factors in end-stage renal disease. Kidney Int Suppl. 2005;94:S46-9.

7. Freedman BI, Robinson TW. Risk factors: familial aggregation of ESRD in Europeans-is it in the genes? Nat Rev Nephrol. 2014;10(12):677-8.

8. Skrunes $R$, Svarstad E, Reisaeter AV, Vikse BE. Familial clustering of ESRD in the Norwegian population. Clin J Am Soc Nephrol. 2014;9(10):1692-700.

9. Kottgen A, Glazer NL, Dehghan A, Hwang SJ, Katz R, Li M, Yang Q, Gudnason V, Launer $L$, Harris TB, et al. Multiple loci associated with indices of renal function and chronic kidney disease. Nat Genet. 2009;41(6):712-7.

10. Kottgen A, Pattaro C, Boger CA, Fuchsberger C, Olden M, Glazer NL, Parsa A, Gao X, Yang Q, Smith AV, et al. New loci associated with kidney function and chronic kidney disease. Nat Genet. 2010;42(5):376-84.

11. Liu CT, Garnaas MK, Tin A, Kottgen A, Franceschini N, Peralta CA, de Boer $\mathbb{H}$ Lu X, Atkinson E, Ding J, et al. Genetic association for renal traits among participants of African ancestry reveals new loci for renal function. PLoS Genet. 2011:7(9):e1002264

12. Chambers JC, Zhang W, Lord GM, van der Harst P, Lawlor DA, Sehmi JS, Gale DP, Wass MN, Ahmadi KR, Bakker SJ, et al. Genetic loci influencing kidney function and chronic kidney disease. Nat Genet. 2010;42(5):373-5.

13. Regele F, Jelencsics K, Shiffman D, Pare G, McQueen MJ, Mann JF, Oberbauer R. Genome-wide studies to identify risk factors for kidney disease with a focus on patients with diabetes. Nephrol Dial Transplant. 2015;30 Suppl 4:iv26-34

14. Padmanabhan S, Melander O, Johnson T, Di Blasio AM, Lee WK, Gentilini D, Hastie CE, Menni C, Monti MC, Delles C, et al. Genome-wide association study of blood pressure extremes identifies variant near UMOD associated with hypertension. PLoS Genet. 2010;6(10):e1001177.

15. Boger CA, Gorski M, Li M, Hoffmann MM, Huang C, Yang Q, Teumer A, Krane V, O'Seaghdha CM, Kutalik Z, et al. Association of eGFR-Related Loci Identified by GWAS with Incident CKD and ESRD. PLoS Genet. 2011;7(9): e1002292.

16. Reznichenko A, Boger CA, Snieder $H$, van den Born J, de Borst $M H$, Damman J, van Dijk MC, van Goor H, Hepkema BG, Hillebrands JL, et al. UMOD as a susceptibility gene for end-stage renal disease. BMC Med Genet. 2012;13:78.

17. Prudente S, Di Paola R, Copetti M, Lucchesi D, Lamacchia O, Pezzilli S, Mercur L, Alberico F, Giusti L, Garofolo M, et al. The rs12917707 polymorphism at the UMOD locus and glomerular filtration rate in individuals with type 2 diabetes: evidence of heterogeneity across two different European populations. Nephrol Dial Transplant. 2016 [Epub ahead of print]

18. Han J, Chen Y, Liu Y, Liang Y, Wang X, Liu L, Wang F, Zhang L, Zhang H, Wang $\mathrm{H}$. Common variants of the UMOD promoter associated with blood pressure in a community-based Chinese cohort. Hypertens Res. 2012;35(7): 769-74

19. Han J, Liu Y, Rao F, Nievergelt CM, O'Connor DT, Wang X, Liu L, Bu D, Liang $Y$, Wang $F$, et al. Common genetic variants of the human uromodulin gene regulate transcription and predict plasma uric acid levels. Kidney Int. 2013; 83(4):733-40.

20. Dupont WD, Plummer Jr WD. Power and sample size calculations. A review and computer program. Control Clin Trials. 1990;11(2):116-28.

21. Barrett JC, Fry B, Maller J, Daly MJ. Haploview: analysis and visualization of LD and haplotype maps. Bioinformatics. 2005:21(2):263-5.

22. Pennica D, Kohr WJ, Kuang WJ, Glaister D, Aggarwal BB, Chen EY, Goeddel DV. Identification of human uromodulin as the Tamm-Horsfall urinary glycoprotein. Science. 1987;236(4797):83-8.

23. Serafini-Cessi F, Malagolini N, Cavallone D. Tamm-Horsfall glycoprotein: biology and clinical relevance. Am J Kidney Dis. 2003;42(4):658-76. 
24. Trudu M, Janas S, Lanzani C, Debaix H, Schaeffer C, Ikehata M, Citterio L, Demaretz S, Trevisani F, Ristagno G, et al. Common noncoding UMOD gene variants induce salt-sensitive hypertension and kidney damage by increasing uromodulin expression. Nat Med. 2013;19(12):1655-60.

25. Liu M, Chen Y, Liang Y, Liu Y, Wang S, Hou P, Zhang H, Zhao M. Novel UMOD mutations in familial juvenile hyperuricemic nephropathy lead to abnormal uromodulin intracellular trafficking. Gene. 2013;531(2):363-9.

26. Moskowitz UL, Piret SE, Lhotta K, Kitzler TM, Tashman AP, Velez E, Thakker RV, Kotanko P. Association between genotype and phenotype in uromodulinassociated kidney disease. Clin J Am Soc Nephrol. 2013;8(8):1349-57.

27. Ahluwalia TS, Lindholm E, Groop L, Melander O. Uromodulin gene variant is associated with type 2 diabetic nephropathy. J Hypertens. 2011;29(9):1731-4.

28. Toyama T, Furuichi K, Shimizu M, Hara A, Iwata Y, Sakai N, Perkovic V, Kobayashi M, Mano T, Kaneko S, et al. Relationship between serum uric acid levels and chronic kidney disease in a Japanese cohort with normal or mildly reduced kidney function. PLoS One. 2015;10(9):e0137449.

29. Rodenbach KE, Schneider MF, Furth SL, Moxey-Mims MM, Mitsnefes MM, Weaver DJ, Warady BA, Schwartz GJ. Hyperuricemia and progression of CKD in children and adolescents: The Chronic Kidney Disease in Children (CKiD) Cohort Study. Am J Kidney Dis. 2015;66:984-92.

30. Renigunta A, Renigunta V, Saritas T, Decher N, Mutig K, Waldegger S. TammHorsfall glycoprotein interacts with renal outer medullary potassium channel ROMK2 and regulates its function. J Biol Chem. 2011;286(3):2224-35.

\section{Submit your next manuscript to BioMed Central and we will help you at every step:}

- We accept pre-submission inquiries

- Our selector tool helps you to find the most relevant journal

- We provide round the clock customer support

- Convenient online submission

- Thorough peer review

- Inclusion in PubMed and all major indexing services

- Maximum visibility for your research

Submit your manuscript at www.biomedcentral.com/submit

) Biomed Central 